\title{
Non-invasive genetic sampling is one of our most powerful and ethical tools for threatened species population monitoring: a reply to Lavery et al.
}

\author{
Sam C. Banks ${ }^{1}$ (D) Maxine P. Piggott ${ }^{2}$ (D)
}

Received: 8 November 2021 / Revised: 12 January 2022 / Accepted: 25 January 2022 /

Published online: 11 February 2022

(C) The Author(s) 2022

\begin{abstract}
Noninvasive genetic sampling (genetic tagging) of individuals is one of the most powerful and ethical tools for threatened species population monitoring. A recent review of the threats to Australia's rock-wallabies (Petrogale spp.) and the methods for their monitoring stated that noninvasive genetic sampling (faecal DNA analysis) is not viable for estimating population size and trends for species in this genus. We feel that it is important to respond as such statements have the potential to stifle the development and application of an important tool for threatened species monitoring and lead to lost opportunities for collection of high-quality data to inform conservation of these species. We take the opportunity to describe the breadth of successful application of noninvasive genetic sampling for monitoring rock wallabies and other mammal taxa, the research and development requirements for successful implementation of noninvasive DNA-based population monitoring and thoughts on why this powerful approach has not been implemented to its full potential in many jurisdictions. We need to be careful not to dismiss one of the most powerful and ethical threatened species monitoring tools due to lack of familiarity with the requirements for its implementation.
\end{abstract}

Keywords Genetic tagging $\cdot$ Petrogale $\cdot$ Threatened species $\cdot$ Mark-recapture $\cdot$ Minimallyinvasive sampling

Lavery et al. (2021) presented a review of the published literature on the Australian rock wallabies (genus Petrogale) to understand key threats and conservation issues and identify informative monitoring tools suitable for guiding conservation management. Rock

Communicated by Adeline Loyau.

Sam C. Banks

Sam.Banks@cdu.edu.au

1 Research Institute for the Environment and Livelihoods, College of Engineering, IT and the Environment, Charles Darwin University, Casuarina, NT 0810, Australia

2 Division of Ecology and Evolution, Research School of Biology, The Australian National University, 44 Daley Road, Acton, Canberra, ACT 2601, Australia 
wallabies are an iconic genus, many species of which are suffering declines and are poorly monitored. In this context, such a review provides an important reference document to inform future investment in conservation actions and the monitoring strategies used to evaluate their effectiveness.

A significant methodological recommendation made by Lavery et al. (2021) was that faecal DNA analysis is presently not viable for monitoring rock wallabies. We believe that this recommendation was not adequately justified and has the potential to stifle the application of one of the most powerful, informative and ethical population monitoring tools available for a data-poor genus. Beyond stating that "the success of trial studies for this method have not been successfully repeated", no published evidence was cited to support the claim, which is out of step with a large body of work demonstrating the operational use of non-invasive genetic sampling methods for rock-wallabies and more broadly for threatened species monitoring both in Australia and globally (Carroll et al. 2018; Lamb et al. 2019).

Faecal DNA methods for monitoring rock-wallabies were first developed for the brushtailed rock-wallaby ( $P$. penicillata) and applied in a monitoring program for that species in Wollemi National Park, New South Wales, Australia. The reasons for the initial development and subsequent application of faecal DNA methods included the difficulty, cost, animal welfare consequences and poor-quality data resulting from the live trapping or 'scat plot' surveys that had been employed for the species previously. The development included the design and evaluation of genetic markers and protocols for identifying individuals from degraded DNA samples (Piggott et al. 2004), evaluation and optimisation of sample collection protocols and DNA extraction methods (Piggott and Taylor 2003; Piggott 2004), followed by application to population size estimation through capture-mark-recapture sampling design and statistical analysis (Piggott et al. 2006a, b). Subsequent applications of faecal DNA methods to Petrogale, some of which were not cited by Lavery et al. (2021), have included quantification of population connectivity in P. brachyotis in the Kimberley region of Western Australia (Potter et al. 2012), simple 'minimum number alive' surveys of $P$. penicillata colonies in Kangaroo Valley and Warrumbungle National Park, NSW (Paplinska 2006; Piggott et al. 2017) and monitoring of post-reintroduction P. penicillata populations in the Grampians National Park, Victoria, following the management decision to cease monitoring via live trapping due to the associated physical disturbance to the population (Kleeman et al. 2022).

Faecal DNA sampling and analysis is particularly valuable for monitoring of rock-wallabies as it is the only approach, besides live trapping and marking of individuals, that enables individual identification, facilitating estimation of population size and demographic rates including survival and recruitment when combined with an appropriate sampling strategy (Piggott et al. 2006a). 'Genetic tags' are permanent so faecal DNA-based markrecapture methods are not susceptible to the tag loss issues that can bias mark-recapture parameter estimation (Arnason and Mills 1981; Malcolm-White et al. 2020). It has the ethical advantage over live trapping in minimising risks to animal welfare (Kleeman et al. 2022) and the logistical advantage that faecal samples (scats) are far easier and cheaper to collect in the field than live animals are to trap. Faecal DNA sampling also provides the 'value add' of data for estimating and monitoring genetic diversity (Kleeman et al. 2022) and population connectivity including immigration rates to monitored populations (Piggott et al. 2006b; Potter et al. 2012), thereby contributing to global efforts to increase monitoring of genetic diversity for conservation (Hoban et al. 2021).

Having outlined some major advantages of faecal DNA sampling, some of the additional requirements that do not apply to the other population monitoring methods reviewed 
by Lavery et al. (2021) include the cost of laboratory analysis and the need for experienced and skilled laboratory scientists to provide high quality genetic data for individual identification. The initial application of faecal DNA analysis to rock-wallaby population monitoring used highly polymorphic microsatellite markers (Piggott et al. 2004) but newer single nucleotide polymorphism (SNP) methods significantly reduce analysis time and cost while increasing genotyping accuracy and comparability among studies (von Thaden et al. 2017). At the time of writing this article, genome assemblies were publicly available for 13 species of rock-wallabies, facilitating the development of SNP markers for population monitoring.

The need for skilled and experienced practitioners is a requirement for obtaining quality data from any environmental monitoring approach, from field-based observation to remote sensing or metagenomics. Our intention is to highlight that partnering with suitably qualified researchers is a basic requirement for successful implementation of faecal DNA analysis and is necessary to identify and overcome technical challenges that are likely to be encountered. Such partnerships need to be developed prior to design of a monitoring program because the design of the field sampling strategy can be dependent on laboratory methods and vice-versa. Ideally, a pilot study would be conducted for a new monitoring program to optimise field and laboratory protocols and here we provide a basic checklist to cover the key considerations of any such pilot study:

1. Identification of genetic markers that can distinguish individuals in the target populations (thereby minimising 'false recaptures' due to failure to distinguish close relatives) and can be genotyped from trace and degraded DNA sources (Sethi et al. 2014). Early applications used microsatellites but SNP panels are now more common (von Thaden et al. 2020) and can be genotyped more efficiently with lower error rates (von Thaden et al. 2017).

2. Optimisation of a sampling strategy to yield accurate genotypes from as high a proportion of samples as possible. This involves quantifying effects of environmental condition and sample storage in the field and laboratory, and DNA extraction method. The sample collection and handling steps, from field to final dataset, are perhaps the most critical for successful application of non-invasive genetics methods and have led to strong differences in genotyping success in our own work.

3. Assessment of the degree of sample replication required in the laboratory to obtain high quality individual genotypes and, ideally, the genotyping error rate. Statistical methods can account for some errors in individual identification for mark-recapture analysis (Lampa et al. 2013; Augustine et al. 2020) and genotype matching software can account for error rates (Jones and Wang 2010) but, ideally, these errors should be minimised through optimisation of field and laboratory practices.

4. Given the constraints resulting from 2 and 3 and the context of the population being studied (How many samples can be obtained and what is the approximate expected population size?), design of a sampling strategy (e.g. to maximise capture probability and minimise individual heterogeneity), for estimating abundance or demographic rates using an appropriate mark-recapture model.

If it is done properly, non-invasive genetic sampling fills a niche for high quality data collection for demographic and genetic monitoring of species. The method continues to grow in application to population monitoring of diverse species globally (Carroll et al. 2018; Lamb et al. 2019). Within Australia, non-invasive DNA sampling has been applied 
in a number of laboratories in government organisations and universities, not only to the study of rock wallabies by a number of research groups but to all three species of wombat (Sloane et al. 2000; Banks et al. 2002, 2003; Walker et al. 2006), the greater bilby (Smith et al. 2009; Dziminski et al. 2021), the ghost bat (Ottewell et al. 2020; Sun et al. 2021), the spot-tailed quoll (Ruibal et al. 2009), the red fox (Marks et al. 2009) and the koala (Wedrowicz et al. 2013; Schultz et al. 2018) and has formed a core method for data collection for long-term monitoring of endangered species (Horsup et al. 2021).

We need to be careful not to dismiss one of the most powerful, ethical and informative threatened population monitoring tools for rock wallabies due to lack of capability or familiarity with the requirements for its implementation. With some notable exceptions (Ottewell et al. 2020; Dziminski et al. 2021), Australia does not have a strong track record of investing in technical expertise in genetics-based methods for threatened species monitoring in its organisations responsible for wildlife management. Our perspective is that, where this has not occurred, this has been a key reason for the lack of wider uptake or effective implementation of non-invasive genetic methods in wildlife conservation. We hope that our response to the review by Lavery et al. (2021) enables informed consideration of whether or not to use faecal DNA analysis in a monitoring program for rock wallabies or other species and some basic guidelines for how to approach the development of a faecal DNA analysis program for population monitoring in a manner that minimises the risk of failure.

Funding Open Access funding enabled and organized by CAUL and its Member Institutions. The authors did not receive support from any organization for the submitted work.

Open Access This article is licensed under a Creative Commons Attribution 4.0 International License, which permits use, sharing, adaptation, distribution and reproduction in any medium or format, as long as you give appropriate credit to the original author(s) and the source, provide a link to the Creative Commons licence, and indicate if changes were made. The images or other third party material in this article are included in the article's Creative Commons licence, unless indicated otherwise in a credit line to the material. If material is not included in the article's Creative Commons licence and your intended use is not permitted by statutory regulation or exceeds the permitted use, you will need to obtain permission directly from the copyright holder. To view a copy of this licence, visit http://creativecommons.org/licenses/by/4.0/.

\section{References}

Arnason AN, Mills KH (1981) Bias and loss of precision due to tag loss in Jolly-Seber estimates for markrecapture experiments. Can J Fish Aquat Sci 38:1077-1095. https://doi.org/10.1139/f81-148

Augustine BC, Royle JA, Linden DW, Fuller AK (2020) Spatial proximity moderates genotype uncertainty in genetic tagging studies. Proc Natl Acad Sci USA 117:17903-17912. https://doi.org/10.1073/pnas.20002 47117

Banks SC, Piggott MP, Hansen BD et al (2002) Wombat coprogenetics: enumerating a common wombat population by microsatellite analysis of faecal DNA. Aust J Zool 50:193. https://doi.org/10.1071/ZO01072

Banks SC, Hoyle SD, Horsup A et al (2003) Demographic monitoring of an entire species (the northern hairynosed wombat, Lasiorhinus krefftii) by genetic analysis of non-invasively collected material. Anim Conserv 6:101-107. https://doi.org/10.1017/S1367943003003135

Carroll EL, Bruford MW, DeWoody JA et al (2018) Genetic and genomic monitoring with minimally invasive sampling methods. Evol Appl 11:1094-1119. https://doi.org/10.1111/eva.12600

Dziminski MA, Carpenter FM, Morris F (2021) Monitoring the abundance of wild and reintroduced bilby populations. J Wildl Manag 85:240-253. https://doi.org/10.1002/jwmg.21981

Hoban S, Bruford MW, Funk WC et al (2021) Global commitments to conserving and monitoring genetic diversity are now necessary and feasible. Bioscience 71:964-976. https://doi.org/10.1093/biosci/biab054 
Horsup AB, Austin JJ, Fewster RM et al (2021) Demographic trends and reproductive patterns in the northern hairy-nosed wombat (Lasiorhinus krefftii) at Epping Forest National Park (Scientific), central Queensland. Aust Mammal 43:72. https://doi.org/10.1071/AM20030

Jones OR, Wang J (2010) COLONY: a program for parentage and sibship inference from multilocus genotype data. Mol Ecol Resour 10:551-555. https://doi.org/10.1111/j.1755-0998.2009.02787.x

Kleeman S, Sandow D, Stevens M, et al (2022) Non-invasive monitoring and reintroduction biology of the brush-tailed rock-wallaby (Petrogale penicillata) in the Grampians National Park, Australia. Aust J Zool ZO21009 Accepted 13 December 2021

Lamb CT, Ford AT, Proctor MF et al (2019) Genetic tagging in the Anthropocene: scaling ecology from alleles to ecosystems. Ecol Appl 29:e01876. https://doi.org/10.1002/eap.1876

Lampa S, Henle K, Klenke R et al (2013) How to overcome genotyping errors in non-invasive genetic markrecapture population size estimation. J Wildl Manag 77:1490-1511. https://doi.org/10.1002/jwmg.604

Lavery TH, Eldridge M, Legge S et al (2021) Threats to Australia's rock-wallabies (Petrogale spp.) with key directions for effective monitoring. Biodivers Conserv. https://doi.org/10.1007/s10531-021-02315-3

Malcolm-White E, McMahon CR, Cowen LLE (2020) Complete tag loss in capture-recapture studies affects abundance estimates: an elephant seal case study. Ecol Evol 10:2377-2384. https://doi.org/10.1002/ece3. 6052

Marks CA, Gigliotti F, McPhee S et al (2009) DNA genotypes reveal red fox (Vulpes vulpes) abundance, response to lethal control and limitations of contemporary survey techniques. Wildl Res 36:647. https:// doi.org/10.1071/WR08109

Ottewell K, Thavornkanlapachai R, McArthur S et al (2020) Development and optimisation of molecular assays for microsatellite genotyping and molecular sexing of non-invasive samples of the ghost bat, Macroderma gigas. Mol Biol Rep 47:5635-5641. https://doi.org/10.1007/s11033-020-05544-X

Paplinska J (2006) Faecal DNA analysis of Petrogale penicillata in Kangaroo Valley. New South Wales National Parks and Wildlife Service, Sydney

Piggott MP (2004) Effect of sample age and season of collection on the reliability of microsatellite genotyping of faecal DNA. Wildl Res 31:485. https://doi.org/10.1071/WR03096

Piggott MP, Taylor AC (2003) Extensive evaluation of faecal preservation and DNA extraction methods in Australian native and introduced species. Aust J Zool 51:341. https://doi.org/10.1071/ZO03012

Piggott MP, Bellemain E, Taberlet P, Taylor AC (2004) A multiplex pre-amplification method that significantly improves microsatellite amplification and error rates for faecal DNA in limiting conditions. Conserv Genet 5:417-420. https://doi.org/10.1023/B:COGE.0000031138.67958.44

Piggott MP, Banks SC, Stone N et al (2006a) Estimating population size of endangered brush-tailed rock-wallaby (Petrogale penicillata) colonies using faecal DNA. Mol Ecol 15:81-91. https://doi.org/10.1111/j. 1365-294X.2005.02783.x

Piggott MP, Banks SC, Taylor AC (2006b) Population structure of brush-tailed rock-wallaby (Petrogale penicillata) colonies inferred from analysis of faecal DNA. Mol Ecol 15:93-105. https://doi.org/10.1111/j.1365294X.2005.02784.x

Piggott MP, Hansen B, Soderquist T, Eldridge MDB, Taylor AC (2017) Population monitoring of small and declining brush-tailed rock wallaby (Petrogale penicillata) colonies at the extreme of their range using faecal DNA sampling. Australian Mammal 40:58-66. https://doi.org/10.1071/AM16056

Potter S, Eldridge MDB, Cooper SJB et al (2012) Habitat connectivity, more than species' biology, influences genetic differentiation in a habitat specialist, the short-eared rock-wallaby (Petrogale brachyotis). Conserv Genet 13:937-952. https://doi.org/10.1007/s10592-012-0342-1

Ruibal M, Peakall R, Claridge A, Firestone K (2009) Field-based evaluation of scat DNA methods to estimate population abundance of the spotted-tailed quoll (Dasyurus maculatus), a rare Australian marsupial. Wildl Res 36:721. https://doi.org/10.1071/WR09086

Schultz AJ, Cristescu RH, Littleford-Colquhoun BL et al (2018) Fresh is best: accurate SNP genotyping from koala scats. Ecol Evol 8:3139-3151. https://doi.org/10.1002/ece3.3765

Sethi SA, Cook GM, Lemons P, Wenburg J (2014) Guidelines for MSAT and SNP panels that lead to high-quality data for genetic mark-recapture studies. Can J Zool 92:515-526. https://doi.org/10.1139/cjz-2013-0302

Sloane MA, Sunnucks P, Alpers D et al (2000) Highly reliable genetic identification of individual northern hairy-nosed wombats from single remotely collected hairs: a feasible censusing method. Mol Ecol 9:1233-1240. https://doi.org/10.1046/j.1365-294x.2000.00993.x

Smith S, McRae P, Hughes J (2009) Faecal DNA analysis enables genetic monitoring of the species recovery program for an arid-dwelling marsupial. Aust J Zool 57:139. https://doi.org/10.1071/ZO09035

Sun R, Ottewell K, McArthur S (2021) Cave use by the ghost bat (Macroderma gigas) in the Brockman mining precinct. Department of Biodiversity, Conservation and Attractions, Perth

von Thaden A, Cocchiararo B, Jarausch A et al (2017) Assessing SNP genotyping of noninvasively collected wildlife samples using microfluidic arrays. Sci Rep 7:10768. https://doi.org/10.1038/s41598-017-10647-w 
von Thaden A, Nowak C, Tiesmeyer A et al (2020) Applying genomic data in wildlife monitoring: development guidelines for genotyping degraded samples with reduced single nucleotide polymorphism panels. Mol Ecol Resour 20:662-680. https://doi.org/10.1111/1755-0998.13136

Walker FM, Sunnucks P, Taylor AC (2006) Genotyping of captured hairs reveals burrow use and ranging behavior of southern hairy-nosed wombats. J Mammal 87:690-699. https://doi.org/10.1644/ 05-MAMM-A-287R2.1

Wedrowicz F, Karsa M, Mosse J, Hogan FE (2013) Reliable genotyping of the koala using DNA isolated from a single faecal pellet. Mol Ecol Resour 13:634-641. https://doi.org/10.1111/1755-0998.12101

Publisher's Note Springer Nature remains neutral with regard to jurisdictional claims in published maps and institutional affiliations. 